\title{
Erratum: Roche, J. The Epithelial-to-Mesenchymal Transition in Cancer. Cancers, 2018, 10, 52
}

\section{Joëlle Roche}

Laboratoire EBI, SEVE, UMR-CNRS 7267, Université de Poitiers, F-86073 Poitiers, France; joelle.roche@univ-poitiers.fr

Received: 12 March 2018; Accepted: 13 March 2018; Published: 19 March 2018

The author wishes to make the following correction to the paper [1]. The following paragraph and the corresponding reference were added [2] (as reference 16 in the Editorial):

"Next, Duchemin-Pelletier et al. present data about the role of CK2 $\beta$, the regulatory subunit of the ubiquitous protein kinase CK2 [16]. In MCF10A mammary epithelial cells where CK2 $\beta$ expression was downregulated, the authors provide evidence that $C K 2 \beta$ downregulation can promote the acquisition of characteristics commonly associated with the cancer stem cell phenotype. They demonstrate that a CK2 $\beta$ level establishes a critical cell fate threshold in the control of epithelial cell plasticity. Since EMT supports the induction stem-cell phenotype, identifying the CK2 substrates will improve the discovery of new specific markers for breast cell stemness."

The reference numbering was also corrected.

The author would like to apologize for any inconvenience caused. The manuscript will be updated and the original will remain online on the article webpage.

Conflicts of Interest: The author declares no conflict of interest.

\section{References}

1. Roche, J. The Epithelial-to-Mesenchymal Transition in Cancer. Cancers 2018, 10, 52. [CrossRef] [PubMed]

2. Duchemin-Pelletier, E.; Baulard, M.; Spreux, E.; Prioux, M.; Burute, M.; Mograbi, B.; Guyon, L.; Théry, M.; Cochet, C.; Filhol, O. Stem Cell-Like Properties of CK2 $\beta$-down Regulated Mammary Cells. Cancers 2017, 9. [CrossRef] [PubMed]

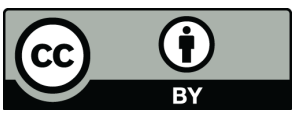

(C) 2018 by the author. Licensee MDPI, Basel, Switzerland. This article is an open access article distributed under the terms and conditions of the Creative Commons Attribution (CC BY) license (http:/ / creativecommons.org/licenses/by/4.0/). 